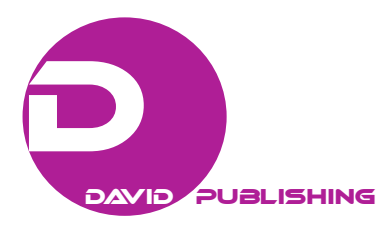

\title{
Postmodern Public Space—Our Destiny
}

\author{
Thomas Hauer \\ VŠB-Technical University of Ostrava
}

\begin{abstract}
The treatise attempts at a philosophical analysis of the category — public area. It points out the dissension between the traditional and postmodern definition of this conception and the consequences resulting from these different attitudes. As far as the methodology is concerned, the study is based on J. F. Lyotard, presenting the postmodern approach as a greater contribution. In postmodern public area, we can meet two basic types of dissentions, while only the first of them can be solved by further grow of specialization and the expert likes to know.
\end{abstract}

Keywords: education, postmodernism, public area, antidualism, antiessentialism

The whole generations of schoolchildren all over the world speak about something that is now official: William Shakespeare is said to be boring, all-fashioned, untrustworthy, and even ridiculous. At least, this is the opinion of a teacher board appointed by the most important province of South Africa, Gautenberg. It suggests to erase some of the playwright's works from compulsory reading lists at all the state schools. They are said to have an unhappy ending very often; they do not express cultural diversity in a sufficient way; they do not condemn racism and sex discrimination, all these principles being included in the South African constitution. The works in question include, e.g., Julius Caesar, because it allegedly does not correspond to the equality between sexes. Other Shakespeare's plays-Antonius and Cleopatra and Taming of the Shrew-do not do well either. In both of them, we label undemocratic, sexist, and racist. Hamlet is marked off undesirable because the play lacks optimism and does not encourage. King Lear is considered as too havenless. According to the board, the play is also full of violence and despair; its plot is unlikely and ridiculous. All the same some Shakespeare's plays manage to escape such judgement, such as Romeo and Juliet, although it is not a happy ending, Macbeth and Merchant of Venice. However, Shakespeare is not the only one to catch a Tatar. Gulliver's Travels are crossed out as well—for containing a sort of humor, which is a far cry from what is close to South African mentality.

Let us take this seemingly funny story as a metaphor suggesting one of the significant problems of the present era. This problem can be expressed by the question: What is the principle of public area in democratic society and how can it be measured? What is the purpose of public area functioning? Is it creating the mass loyalty or restoring the idea of the society as a whole, which none of us as an individual really has, into our versions of the world?

There are a lot of keen supporters of the first option nowadays, including a university professor and an influential philosopher Marcello Pera. In his speech at Lateran University in Vatican, he says: Today an idea prevails in the west that none of the intellectual constructions has a universal acceptance. Pera warns against the

Thomas Hauer, Assoc., Prof., Ph.D., Department of Social Science, VŠB-Technical University of Ostrava, Czech Republic; main research field: Postmodern Philosophy, Contemporary Philosophy, Philosophy of Technology, Ethics, and Philosophy of the 20th century. Email: tomas.hauer@vsb.cz. 
influence of such philosophers as Nietzsche, Derrida, or Deleuze. These thinkers preach an unacceptable thesis that is reducing the European civilization to one of many cultures. The history of the west is replenished: It resigns to the universal nature of Western thought, laws and institutions, the chairman of the Italian Senate states. The base of the approach presented by Marcello Pera is such a conception of public area which assumes a possibility that gives definitive reasons for your options by grounding them on some undisputable evidence or universal system of rules, which must be acknowledged in it by every sensible person. Such a conception of public area therefore looks for absolutely just view where our version of the world is not conditioned by anything, so we can see the truth or we can see the things as they are in reality.

A different approach to understanding the conception of public area can be found with philosophers who are usually called postmodern. The plot of the story offered to us by these authors in different varieties could be summarized as follows: Let us found the open society of the Western type on the assumption of fallibility of all its participants. The fallibility in private, political, or economic decision-making means that every purposeful and intentional behaviour has some consequences which have not been considered before (Deleuze 1983, 149). Therefore, the sensibility of our conduct is not guaranteed by the perfect state of our theoretic ground, which is always imperfect. However, it can be brought about by institutions like free market, independent public opinion, or effective public area - compelling us to a change, quick recognition, and rectification of those unmeant consequences of our decisions. Our sensibility is measured not only by finding a suitable solution, but also by our flexibility — that is how quickly we are able to react to the crisis of our initial ground caused by the fact that the society as a whole never reacts according to the assumption of the theoretical ground.

I would like to use the following example to illustrate as the case would stand if we described them by means of postmodern mode of speech. In his successful book The War of Sperms, an American zoologist Robin Baker describes the ability of sperms to attack the sperms from the previous copulation which fertilizes the ovulum. Baker comes to the conclusion that human sperms - like male generative cells of a number of other animal species — not only can compete with each other. The sperms of one male also have a destructive effect on his "predecessors." Individual species from dragon fly to chimpanzee have developed various methods to ensure that the last male's sperms surpress other male's sperms and the female copulates with short ago in her organs. Baker expresses an assumption that men produce special "kamikaze" sperms exploding in close proximity of other individual's sperms and destroying them by this. This feature, for the rest as everything in nature, must have had some cause. If we bring it to a close, Baker deduces from this that men are in their biological nature used to changing partners. Mišel Siva-Jothy from the University of Sheffield does not agree with him and claims that in a woman's organism there are mechanisms checking the quality of the received sperms. Namely the quantity of waste is high and woman organs test the sperms carefully.

In public area of postmodern society, we solve problems of two kinds. Firstly, there are problems that can be solved by further growth of specialized knowledge. The dispute whether men produce "kamikaze" sperms or not can be untwined by increasing the disputants' competence. R. Baker and M. Siva-Jothy can then settle their argument, e.g., by more careful observation, more complete documentation of the problem, or more thoughtful generalization of the facts, broadening the comparative sample, enforcing a miniature camera, using a revolutionary scientific method, etc.. Similar situation concerns the questions: whether organized criminal activity grows; whether the inflation increases or decreases; whether T-neutrins exist; whether the influx of foreign investment rises or falls; whether the drug abuse among teenagers grows and so on. Secondly, in public area, we meet problems that cannot be solved by further growth of specialized knowledge. The inhabitants of 
Iceland, a small island in the north part of the Atlantic, have unwillingly become involved in a unique and controversial experiment. The Iceland's government sells the genetic information and lines of descent of all the Icelanders to the commercial firm Decode Genetics, which will use this material to try to disclose the genetic ground of the inherited diseases and prepare new procedures to cure them. The government in Reykjavik is offered by the firm to be paid 200 million dollars in the course of the next five years for the overall information about DNA, inheritance carrier.

The Island's population, whose language belongs to the Germanic branch of the Indo-European family, is regarded as one of the most homogenous populations in the world. Since the ninth century when the Vikings' fleet from Norway landed on the island, its genetic ground changed as late as 100 years later-at that time several hundred Scotsmen and Irishmen settled on the island. Settlement records, church registers, regular census and even carefully kept lines of descent cannot be compared to anything else in the world. The Islanders collect their long ago deceased ancestors as others collect stamps. The transaction between the government and the Decode Genetics arouses a number of questions. Besides the ethical questions concerning commercial use of genetic heritage of a nation, there are issues of the privacy and agreement of the individuals, their rights against the state, etc.. According to Thomas Zoega, the chairman of the ethical board of the Iceland's Medical Association, the government takes an illegal action by selling sensitive personal data without the approval of the people it concerns. Doctor Kari Stefansson, a charismatic founder and boss of the Decode Genetics, avows that he has bought a treasury of genetic information. He is absolutely confident that accessing the information will signify revolution not only in Iceland, but all over the world. The above stated questions, similar to the questions - whether we should reconcile to overwriting DNA with plant and animal species; whether education system should be considered as private or public property; whether globalization brings about economic growth and well-being or ecologic degradation; what is progress or whether the existing abortion law should be made more strict — cannot be answered by further growth of the specialized knowledge, referring to universal truths or a more complete enumeration of facts.

These questions can only be resolved by uncovering hidden moral, historical and value prerequisites of the stories in which these issues are assessed and evaluated. French postmodernist J. F. Lyotard offers us the following methodologist approach. He shows that each perception not only includes imperfection, but this separation, this selection is absolutely essential for our ability to perceive. To put something on the map means to make something else - the background, outside, against the surrounding - invisible in a way, to force out other structure into the latency state or oblivion. Every problem, theory, or event attracting our attention, offers us something or brings a wide choice of new opportunities, therefore it is a visible shape thanks to the power of separation. However, in the end, the background overpowers the shape, and transfigures it by incorporating it into the co-existence with the rest of the world and our preceding experience. Let us use Lyotard's term for the second type of the questions appearing in public area and let us call them the background questions (Lyotard 1983, 39). What we mean is the fact that e.g., the question of cloning men or interfering in human DNA for medical purposes will certainly have different background for those who live their lives in the creation story and for those of us who believe in evolution.

In the background of these two stories, there are two fascinating metaphors with their own poetics, the gracious God the Creator versus a selfish gene, which contradict each other. Public area has its tension because those great metaphors crash all the time while solving various topics, their dispute making us better people and increasing the quality of our decision-making and making it more legitimate. The questions, whose background 
is created by those great metaphors, cannot be solved by a more professional argumentation, the expert's impersonal jargon, or accumulation of universal truths (Lyotard 1984, 42-49). Postmodern public area emphasizes the second type of the questions, making the dispute of those great metaphors more dramatic. Thanks to the conflicts they invoke, these metaphors open up the questions in the background for us, whose charming power we do not realize in the whirl of everyday life. A process called globalization entangles postmodern public area in unsolvable antimonia. It is I. Kant who gives the status of philosophical term to the word antinomy. He denotes it as insolvable issues inherently connected with the existence of mankind. The questions - does the world have any beginning or is it infinite; is it complex or simple; is everything in it rightful or accidental — can never be answered in a definitive way, because both thesis and antithesis are acceptable. It only depends on how we envisage the question. According to Kant, a liberal state has its own role which cannot be replaced by anything else. All the time, it must guard its citizens against the fanaticism of the searchers for the definitive solutions, who are not able to bear the fact that the situation of mankind is very problematic. Thus, the promise of "final solution" is the archetype and the largest intellectual temptation of modern style.

Antimonies highlighted by public area do not have a definite solution then; they can only be stabilized, i.e., be deprived of their potential destructiveness. Within the present paradigm, an attempt at their final solution would lead to unbearable cultural, political, and social conflicts. The contradictions of late industrial society cannot be overcome, nevertheless the trust in positive results, their visualization in public area of democratic societies is still the goal and the purpose of the western cultural tradition and may be the last legitimate source of the intellectuals' authority.

Most of you probably remember Miloš Forman's film Masses versus Larry Flynt, which was awarded Gold Bear at the Berlin festival in 1996. The main motto of the film is freedom for unpleasant ideas. It is a life story of the porno-king, the founder of Larry Flynt's magazine Hustler. This magazine (and many others), which is full of sexual obscenities according to many Americans' opinion, is for the Flint on the other hand, the means of fighting against the censorship and prejudice exerted both by the government and the churches trying to force on the people their own morals. Flynt who is paralyzed after the attempt on life in 1978 and moves on a gilded wheelchair says in one of the key scenes of the film: If you protect my freedom to utter unpleasant ideas and opinions in public now, you will protect yourselves, because I am the worst one now. It is just the unpleasant opinions that need freedom; the conform ones surely do not need it. This could be the message — scandalous for many people — of Forman's film. Postmodern public space is our destiny.

\section{Works Cited}

Gilles, Deleuze. Nietzsche and Philosophy. Minneapolis: University of Minnesota Press, 1983.

Jean-François, Lyotard and Jean-Loup, Thébaud. Just Gaming. Minneapolis: University of Minnesota Press, 1985.

Jean-François, Lyotard. Driftworks. New York: Semiotext(e), 1984.

Richard, Rorty. Contingency Irony and Solidarity. Cambridge: Cambridge University Press, 1989.

---. Philosophy and Social Hope. New York: Penguin Books, 1999.

---. Truth and Progres. Cambridge: Cambridge University Press, 1998. 